\title{
災害復興における住民組織による調整 仙台市宮城野区の事例
}

\section{Study on adjustment of opinion in disaster revitalization process:}

The Case of Miyagino

\author{
小林秀行 \\ Hideyuki KOBAYASHI
}

Adjustment is an important issue to solve conflict or antipathy about disaster revitalization in sociology. The purpose of this paper is to describe the process in which residents of a disaster damaged area adjust differences of opinion around revitalization by using the case study of Minamigamou and Shihama, Miyagino, Sendai.

After the Great East Japan Earthquake, Sendai city office designed disaster danger area including Minamigamou and Shinhama areas that it planned mass relocation project. The anti-relocation movement against this plan is a turning point that residents of these two areas deal with revitalization positively. After that plan revised, residents of Minamigamou and Shinhama established new institution for revitalization as the name of "Minamigamou Hukkoubu" and "Shinhama Hukkou no Kai". Two institutions have been worked to solve 3 issues, "housing reconstruction and relocation" "dropout of younger members" "construction plan of evacuation tower and road" by adjustment differences of opinion. As a result, "Minamigamou Hukkoubu" succeeded to keep their community through collision but "Shinhama Hukkou no Kai" failed to keep their community.

The academic significance of this research is as follows. An important thing of adjustment which is practiced by community organizations under disaster revitalization process is that how institutions keep the backing of their residents' opinion. "Minamigamou Hukkoubu" has practiced "being receptive to various opinion" "guaranteeing multiple routes to participate" "guaranteeing multiple opportunities to participate" to retain the backing of it. Then, "Minamigamou Hukkoubu" has maintained its position which is the representative organization of residents through some fails on negotiation with Sendai city office. On the other hand, "Shinhama Hukkou no Kai" has not practiced these three things sufficiently. So, it failed to keep the backing of their residents' opinion.

\section{1. 問題の所在}

東日本大震災の発生から 3 年が経とうとしている。被災地が復興に向けて取り組みを続 けてきた、この 3 年の間、復興への住民参加、住民意見の反映は常に重要視されてきた。 
社会学の立場においても災害復興における住民参加について、近年、研究の蓄積がなされ ている [例えば今野, 1999 ; 浦野・大矢根・吉川編, 2007 ; 室井, 2011] が、首都直下地 震、東海・東南海地震の切迫性が高まる我が国において、被害軽減とその後の速やかな復 興の為には、さらなる研究、議論の蓄積が必要と考えられる。この問題は決して理念的な 問題ではなく、たとえば阪神淡路大震災の復興において、当時の被災自治体であった神戸 市が、被災住民との意見調整を十分に行わないままに策定した都市計画案に対して、今日 まで続く大きな批判があったわけである [飯塚, 2013：90-101]。

一方で、復興においては迅速性が求められる。神戸市が、上述のような批判を受けなが らも、早急な計画策定に動いたことが、震災から 2 ケ月後という短期での「神戸市復興ガ イドライン」策定に繋がった事も事実ではある。しかし、この点についても、行政主導の 計画がもたらす問題に対する多くの批判的な研究 [例えば塩崎ほか, $2005: 192$; 山中, 2006］が行われ、迅速性という問題においても、行政主導に対抗するために、住民参加は 求められているのである。

とはいえ、災害とは「長期的な社会過程」[田中, $2013 ： 281]$ であり、復興もまた長期 にわたる。たとえ、復興計画の策定に住民意見の反映が十分に行われたとして、そこで住 民による復興への取り組みが終わるわけではなく、被災地が従前の姿を取り戻すまで、住 民は地域の復興を推進していくことが必要となる。山下祐介が、近代国家という広域シス テムの発展の中で失われた住民の主体性を、地方自治への転換によって再度獲得していく ことが、今後の災害に対抗するために重要であると指摘していることは、そうした長期的 な過程への視点を踏まえてのものであろう [山下, $2013: 43-45]$ 。

住民における、長期的な復興を担う主体についての研究は、雲仙普賢岳噴火 [鈴木, 1998］から展開し、北海道南西沖地震 [南・野島, 1994]、阪神淡路大震災 [例えば宮定, 2007]、新潟県中越地震 [松井, 2008] などを事例として研究がなされている。これらの研 究によれば、住民による長期的な復興の主体は、地域においては町内会など住民組織に よって担われてきている。こうした組織は、町内会研究 [辻中ほか, 2009] や地域防災 [浦 野, 1984]に関する研究などではその弱体化が指摘されているが、上述の事例研究におけ る災害は、コミュニティが被災当時でも機能していた地域で主に発生しており、そこには 復興を主導する住民組織の存在があった ${ }^{1)}$ 。先行研究からは、これらの組織は、その成立 過程や基盤はさまざまであるが、最終的には、いずれの被災地でも合意形成を推進するた めの組織が台頭していることが特徵である。横田尚俊はこのような組織を、対決・要求型 の組織とは異なる、「調整型組織」[横田, 1995：52] と定義し、復興に関わる利害や志向 について、意見集約と行政協調型の交渉を行うことによって、分断された地域社会の再構 築を担っていくと捉えている。

この事害の理解として、鈴木広の分析が明快である。鈴木は、長期災害という問題に対 して、コミュニティの成員が個々に対処するのか、一丸となって対処するのかという二択 
を迫られた時、もしコミュニティを維持したままに復興を成し遂げようとするのであれ ば、「“実態としてのコミュニティ”と“規範としてのコミュニティ”」[鈴木, 1998 :32-33] との間に、現実的な方向性を見出し、地域コミュニティを形成していかざるを得ないと指 摘している。このための解決策の 1 つが、上述したような調整型組織、住民組織による住 民意見の調整なのである。この調整という視点は、既往の災害においても重視されてきた 視点であり、また、東日本大震災をテーマとして取り扱う幾つかの学会においても、論点 の 1 つなっている ${ }^{2)}$

\section{2. 調査の概要}

しかしながら、震災以降の研究動向をみるところ、東日本大震災からの復興に関する研 究は、津波による犠牲者の多い三陸リアス部、そして福島第 1 原子力発電所事故からの避 難問題に取り組む福島県沿岸部に関心が集まっているように見受けられる。その反面、両 地域の中間に位置する仙南平野部に関しては、事例研究は少数に留まる [例えば石川, 2011 ; 星山, 2012]。なお、ここでいう仙南平野部とは、宮城県南部の仙台市、名取市、 岩沼市、亘理町、山元町の 5 市町を指すものとする。この仙南平野部は農業地帯であると ともに、政令指定都市である仙台市を中心とした大都市圈であるともみることできる。

災害研究という観点からいえば、本震災における仙南平野部の被災とは、1995年の阪神 淡路大震災以来の、大都市圈が災害によって大規模に被災したという事例である。無論、 三陸リアス部の復興や福島県沿岸部の広域避難問題も極めて重要な視点ではあるが、同時 に、我が国で想定されている首都直下地震、東海・東南海連動型地震に向けた防災を考え る上で、本震災における仙南平野部の被災について、事例研究を行っておく意義は大きい と考えられる。

本稿では、このような観点から調査対象地として仙南平野部に着目した。2012 年 7 月か ら 8 月にかけて、仙南平野部の 5 市町の状況について、現地調査および新聞報道や各組織 の広報資料を用いた予備調査を行った。その結果、5 市町の被災状況は住宅流失と農地の 浸水が主であり、それに対する自治体の復興方針は名取市を除いて、防災集団移転事業に よる居住地の内陸移転と、農地および港湾の再整備を基本とするという傾向で一致してい た。名取市の場合は、現在では現地再建と防災集団移転を併用しているが、予備調査の時 点では現地再建のみを推進しており、内陸移転を求める住民の反対を受け、合意形成に苦 慮していた。

5 市町で住民による地域レベルでの復興に向けた活動として動きが見られたものは、筆 者の調査の限りでは 21 組織（表 1) あり、このうち組織活動の活発度の代理指標として、 組織自身が組織の設立趣意・目的を公表している組織を抽出すると、11組織存在した。こ れら 11 組織について、組織の活動として地区全体の意見集約が行われているかを資料か 
表 1 仙南平野部における復興のための地域住民組織一覧

\begin{tabular}{|c|c|c|c|c|}
\hline 市町 & 組織 & 組織の趣意・目的 & $\begin{array}{l}\text { 組織による趣意・ } \\
\text { 目的の公表 }\end{array}$ & $\begin{array}{l}\text { 地区全体の } \\
\text { 意見集約 }\end{array}$ \\
\hline \multirow{9}{*}{ 仙台市 } & 南蒲生復興部 & 現地再建・移転再建 & あり & あり \\
\hline & 新浜復興の会 & 現地再建・移転再建 & あり & あり \\
\hline & 北蒲生のまちづくりを考える会 & 災害危険区域指定撤回 & なし & なし \\
\hline & 蒲生二丁目土地区画整理事業を考える会 & 土地区画整理事業計画撤回 & なし & なし \\
\hline & 中野小学校区復興対策委員会 & 防災集団移転・土地区画整理 & あり & あり \\
\hline & 荒浜再生を願う会 & 災害危険区域指定撤回 & なし & なし \\
\hline & 荒浜移転まちづくり協議会 & 防災集団移転 & なし & なし \\
\hline & 明日の三本塚を考える会 & 現地再建・移転再建 & なし & あり \\
\hline & $\begin{array}{l}\text { あすと長町仮設住宅共助型コミュニティ } \\
\text { 構築を考える会 }\end{array}$ & 「共助型」復興住宅づくり & あり & なし \\
\hline \multirow{2}{*}{ 岩沼市 } & 玉浦西地区まちづくり検討委員会 & 防災集団移転 & あり & なし \\
\hline & NPOがんばッと！！玉浦 & コミユニティ再生・農業再生 & あり & なし \\
\hline \multirow{6}{*}{ 名取市 } & 閖上復興まちづくり推進協議会 & 区画整理事業による現地再建 & あり & なし \\
\hline & どうする䦭上 & 地区全体の復興まちづくり & なし & なし \\
\hline & 闒上復興・まちづくりを考える会 & 地区全体の復興まちづくり & なし & なし \\
\hline & 新生なとり市民の会 & 地区沿岸部の復興まちづくり & なし & なし \\
\hline & 名取市東部震災復興の会 & 地区沿岸部の復興まちづくり & なし & あり \\
\hline & 北釜被災者の会 & 復興まちづくり・防災集団移転 & あり & あり \\
\hline \multirow{3}{*}{ 亘理町 } & 復興非営利団体 わたり・あらはま & 現地再建 & あり & なし \\
\hline & 大畑浜を守る会 & 災害危険区域指定撤回 & なし & なし \\
\hline & わたりグリーンベルトプロジェクト & 防潮林再生 & あり & なし \\
\hline 山元町 & 山元町 震災復興 土曜日の会 & 沿岸旧市街部の再生 & あり & あり \\
\hline
\end{tabular}

(出典：各団体資料・記事より筆者作成)

ら分析したところ、表 1 に示した通り 5 組織があげられた。ただし、名取市、山元町の 2 組織については、行政との関係性という側面で課題を抱えており、行政協調型の交渉とい う調整型組織の特徵を十分満たしていないとみられたため除外し、仙台市内の 3 組織を対 象とした。

各組織に対する調査に先立つて、災害調査の道義性を鑑み、仙台市の復興状況及びこれ らの組織の状況と調査可能性について、仙台市役所および仙台NPOサポートセンターの 職員に対して、それぞれ聞き取り調査を 1 回行った。その結果として、3 組織のうち 2 組 織については調査可能と考えられ、また両地区の調整型組織の代表者を紹介頂けたため、

宮城県仙台市宮城野区南蒲生地区、同区新浜地区を調査対象地として最終的に決定した ${ }^{3)}$ 。 両地区は、ともに地区内に災害危険区域を抱え、住宅の現地再建を行う住民と移転再建を 行う住民が同時に存在している（図 1)。

調査は 2012 年 8 月末より開始し、南蒲生地区については、後述する南蒲生復興部部長 $\mathrm{H}$ 氏に対する 1 時間程度の聞き取り調査を 2 回、さらに 2014 年 2 月現在に至るまで、毎月の 


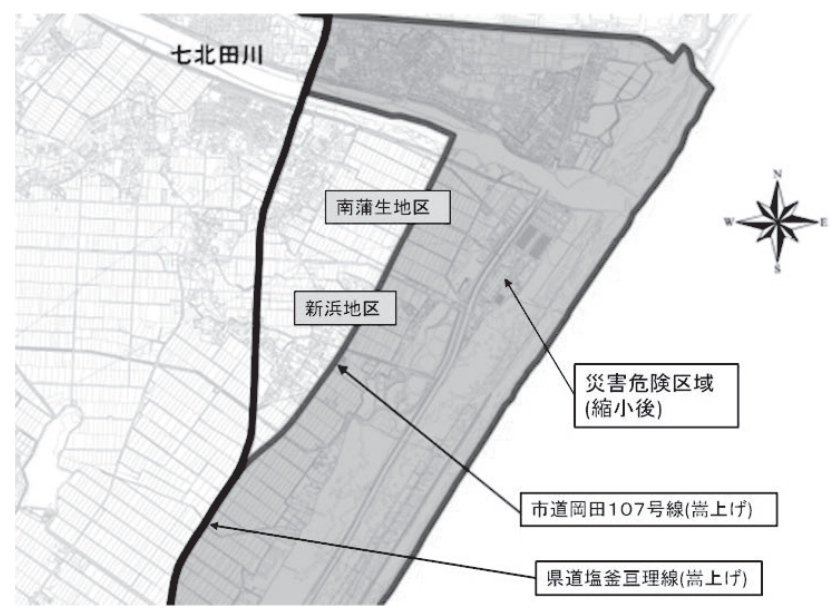

(出典：仙台市, 2011,「災害危険区域図（A3 版・条例第 2 条第 5 号）」より筆者一部改変）

図 1 南蒲生・新浜地区の位置と災害危険区域

第 4 土・日曜日に実施されている定例会に同席しての観察調査を、述べ 27 回 ${ }^{4)}$ 実施し、 現在も継続中である。新浜地区については、2013年 1 月に新浜復興の会世話人代表 $E$ 氏に 対する聞き取り調査を実施した。この聞き取り調査の結果、地区の復興は、初動段階にお いて深刻な問題が発生していることが明らかとなった。同地区における観察調査は、地区 の混乱を助長させる可能性がある事から中止し、復興情報誌の記者や地区の復興を支援す る専門家に対して、4 半期に 1 度程度の頻度で復興状況の聞き取り調査の実施および、復 興情報誌や新聞記事による文献調査を行うに留めている。

よって、以降では南蒲生地区における観察調査の結果を中心的に取り扱い、新浜地区に ついては、比較対象として簡単な説明を行うに留めるものとしたい。

\section{3. 南蒲生地区}

\section{1 南蒲生地区の概況}

本稿が分析の中心とした宮城県仙台市宮城野区南蒲生地区は、今次震災からの復興に際 して、このような住民組織による調整が、復興の取り組みが始まった段階から一貫して行 われてきた地区である。

南蒲生地区は、地区の町内会組織である南蒲生町内会の範囲を指し、地区の人口は 892 人 290 世帯 $\left(2011\right.$ 年 2 月時点) である ${ }^{5)}$ 。農業地帯である仙南平野部の北側に位置し、全世 帯のうち約 80 世帯程が農家である。また、防風・防砂林として、伝統的な屋敷林である 居久根の景観が形成されていた地区でもある。地勢としては、海抜 $5 \mathrm{~m}$ ぼ゙の丘状の土地 
であり、鎌倉期頃には既に集落が形成されていた。その後、江戸期に新田開発がなされ、 現在の形となった。この際、仙台藩より開発指揮の命を受けた武家が移住しており、現在 でも地区の名望家として扱われている。今次震災の復興においても、活動の中心に一族か ら複数名が位置していることは、地縁関係の強固さを物語るものといえよう。とはいえ、 戦後以降から、県道の開通や宅地化など徐々に開発も進んでいる。

東日本大震災では、太平洋および七北田川の 2 方向から津波を受け、地区全域が被災し た。犠牲者は、谷謙二の分析によれば、南蒲生地区と隣接する新浜地区をあわせて 115

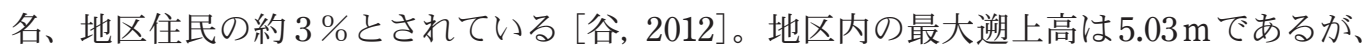
既述のとおり住宅地は丘陵に形成され、低地部も海岸から $1.5 \mathrm{~km}$ ほどまでは農地利用が大 部分であったため、家屋の流失は比較的少ない。仙台市の被害状況図から見る限り、地区 の約 7 割の家屋は津波による被害を受けたものの、流失は免れている。

では、このような地区において、住民による復興への取り組みはどのように始められた のであろうか。

\section{2 南蒲生地区の住民組織}

\subsection{1 南蒲生復興部設立までの経緯}

南蒲生地区において、住民の活動が本格化したのは 2011 年の 10 月以降のことである。 住民は同年の 7 月頃から仮設住宅への入居を開始しており、この時期には、避難生活が一 段落を迎えていた。地区内は未だに瓦碟、流木などが散乱していたものの、流失を免れた 家屋が多かった事もあり、住民は現地での住宅再建が可能であると予測していた。

しかし、仙台市が 10 月上旬に発表した復興計画の中間案において、南蒲生地区は地区 を東西に分ける県道塩釜亘理線以東の全域が災害危険区域に指定され、南蒲生地区住民 290 世帯のうち 119 世帯が集団移転の対象となる事が判明した。この案に対して、現地再 建を求める南蒲生地区住民は、南蒲生町内会を代表として、仙台市に対して危険区域指定 の再検討を要請した。その後、仙台市側でも県道のかさ上げによる第 2 線堤化 ${ }^{6)}$ などを含 めた検討の結果、11月30日に策定された仙台市復興計画では、南蒲生地区に対する災害 危険区域指定の範囲は縮小され、区域に含まれる住民は16世帯にまで減少した。

南蒲生地区は、復興に向けて仙台市の縮小案を受け容れる一方で、それにより、地区内 に現地再建派と移転再建派という 2 つの集団を抱えることとなつた。すでに、中間案の再 検討要請の段階で、住民側に復興を担う組織の必要性が認識されていたこともあり、南蒲 生地区の復興組織設立が、この時点で構想されることとなる。復興組織は、当初の構想で は町内会を中心として、婦人会や老人会といった地区内の既存組織の長を集めた連絡会が 考えられていたようであるが、最終的には町内会の 1 部会、「南蒲生復興部」として組織 されている。その理由は、聞き取りによれば、「地区の復興まちづくりを一体的に推進」 [南蒲生町内会, 2013] するという理念のもとで、仙台市との交渉など活動を具体的に進め 
る能力が求められた為とのことである。

なお、南蒲生復興部は 2012 年 1 月 15 日の町内会総会で、住民の承認を受けて設立され たが、この総会では町内会役員の交替も起こっており、町内会長はこの時点から地区の名 望家へと交替している。定年退職後から町内会に携わる T氏によれば、震災以前の町内会 役員とは「地域の出身者でありさえすれば、別に誰でも良い。なりたい人がなる」程度の ものであったとのことであり、1月15日の町内会総会は、このような平常時の組織体制か ら、震災対応へと、町内会全体が体制を整えた場であったといえるだろう。

復興部の部長は、町内会長や役員の兼任ではなく、新たに 60 代男性の H氏が据えられ ることとなった。H氏は地区の出身ではあったが、会社員として勤務しており、震災以前 には町内会など住民組織への関与は薄かった。

その一方で、H氏は震災以前から、西町会と呼ばれる同空会組織に参加し、南蒲生の周 辺地区までを含む独自のネットワークを用いて交流を行っていた。この西町会の参加者は 現在、定年を迎えてから数年の 60 代半ばにあり、地区の中心として活動を行う世代と なっている。南蒲生地区でも、H氏以外に西町会参加者の復興部員が存在しており、その 中には地区に居住し、町内会に関わってきた住民もいる。H氏はそれまで町内会への関与 が薄かったものの、このようなネットワークを通じて、町内会長からの打診を受け、復興 部部長の役職を引き受けることとなつた。

H氏は、復興への方針として、「まちづくりには地域産業が伴い、生活基盤が整うこと が必須。新たなまちづくりの可能性として、今後、再生可能エネルギーに取り組んでいき たい」（仙台市, 2012）と、住宅再建と新たな地域産業形成による地域再生を打ち出し た。そして、復興に向けて「参加する人は、相手の意見を否定せずに平等な立場で受け止 めてほしい」と語っており、住民全体での議論を重視した組織運営を行っている。

\section{2 .2 南蒲生復興部の概要とその活動}

南蒲生復興部 (以下、復興部) は、約 20 名の復興部員によって構成され、復興に向けた 議論の場として毎週（現在は隔週）の定例会と、毎月の町内会説明会を開催している。ま た、住民意見の集約の為に、一般住民を集めての会議やワークショップも開催している。 組織としては町内会の 1 部会だが、復興に関わる判断については、町会の承認を待たず に、事後に追認を受ける形で意思決定を行う事が出来る。これは通常の町内会の意思決定 過程から逸脱した方法であり、この意味で、復興部は地区の復興の為に、既存の体制を変 更して特別に組織された部会であるといえる。

復興部の主要な構成員である復興部員は、これまで町内会への参加が高かった世带主層 を中心に、一部、若手住民も含まれており、定例会への出席率は最低でも 5 割以上を保つ ている。ただし、ほとんどが旧住民であり、新興住宅地に居住する新住民の関与は薄い。 この意味で、復興部は震災対応に向けて、地区の体制を一新して臨む形ではありながら 
も、震災前の町内会がもっていた地縁関係が反映されていることも事実である。

とはいえ、新住民を含む一般住民の活動への参加経路が無いわけではなく、定例会、町 内会説明会ともに住民であれば参加自由であり、復興部側からは活動の度に、一般住民に 対して積極的な参加を求める発言がされている。一般住民の参加としては、世带主層であ る 60 代以上の男性を中心に、ワークショップや町内会説明会への参加が主である。参加 者数は、活動の内容によっても変動するが、概ね 50 名〜 70名程度の参加がある。世帯か ら平均 1 人の参加と考えれば、 290 世帯中の約 2 割程度が活動に関与していると考えられ る。

このようにして活動が始まつた南蒲生復興部は、現在までに大きく 3 つの課題に直面し てきた。すなわち、「I ：住宅再建の取りまとめ」「II : 若手の離脱」「III：避難施設・避 難道路整備」である。これらの課題に対して、南蒲生地区は復興部を中心として、都度に 対応を実施していくことになる。以下では、それぞれの課題について、経緯と現時点での 状況をみていくことにしたい。

\section{3 南蒲生地区の復興過程}

\subsection{1 住宅再建の取りまとめ}

住宅再建の取りまとめ、とくに現地再建可能な世帯についての意見調整は、復興部が直 面した最初の課題であり、復興部が設立されたそもそもの原因でもある。仙台市の復興計 画の修正によって、一部を除いて現地再建が可能とはなったものの、地区住民の中には、 津波への恐怖心などの理由で内陸部への移転を希望する世帯も存在した。また、一口に住 宅再建と言つても、方法は様々であり、更にその先の地域再生という段階にまでなれば、 希望はさらに細分化されることが予想された。

復興部では、住民意向の集約の為に、2012 年 1 月からの 1 年間で、アンケート調査を 2 回、ワークショップを 3 回、再建方法別の住民検討会を各 8 回実施している。この際、復 興部は、H氏が「喧嘩にしてはいけないという事は、当初から口を酸っぱくして言ってき た」と語るように、各住民の再建方針や助成制度の差異が、住民間の対立や分断を引き起 こさないよう、現地再建派と移転再建派ごとに議論を集約し、両集団を仲介することで、 地区の全体的な復興計画を検討する場として機能した。

住民の再建意向としては、2012 年 5 月に実施された、復興部による第 1 回アンケート調 査の結果に示されている通り、147世帯中の 89 世帯 $(60.5 \%)$ が現地再建を希望している (表 2)。エリア別に見た際には、海岸により近く、全壊率の高い県道東側で、移転再建を 希望する割合が高くなつており、津波に対する恐怖、警戒心が高いとみることができる。

しかし、現地再建世帯はこの後、時を経るごとに増加し、2013年11月時点では全 218 世帯中の 146 世帯 $(67.0 \%)$ が現地での住宅再建を希望し、うち 134 世帯は再建を完了して いる (表 3 )。また地区内移転世帯は 16 世帯であり、これを含めれば74.3\%が地区内での 
表 2 南蒲生町内会による住宅再建意向調査

\begin{tabular}{|l|c|c|c|c|c|c|c|c|c|}
\hline \multirow{2}{*}{ 調査時期 } & $\begin{array}{l}\text { 配布数 (町内会 } \\
\text { 加入世帯数) }\end{array}$ & $\begin{array}{c}\text { 有効 } \\
\text { 回答数 }\end{array}$ & \multicolumn{2}{|l|}{ 回収率 } & \multicolumn{2}{|c|}{ 現地再建 } & \multicolumn{2}{|c|}{ 移転再建 } & \multicolumn{3}{|c|}{ 災害危険区域 } \\
\hline 2012.5 & 235 & 147 & $62.6 \%$ & 89 & $60.5 \%$ & 52 & $35.4 \%$ & 6 & $4.1 \%$ \\
\hline 2012.11 & 235 & 104 & $44.3 \%$ & 71 & $68.3 \%$ & 28 & $26.9 \%$ & 5 & $4.8 \%$ \\
\hline
\end{tabular}

（出典：南蒲生復興部会議資料より筆者作成）

表 3 南蒲生町内会による住宅再建状況調査

\begin{tabular}{|c|c|c|c|c|c|c|c|c|c|}
\hline \multirow{2}{*}{ 調査時期 } & \multirow{2}{*}{$\begin{array}{c}\text { 町内会 } \\
\text { 加入世帯数 }\end{array}$} & \multicolumn{2}{|c|}{ 現地再建 } & \multirow{2}{*}{$\frac{\text { 地区内移転 }}{\text { 再建済み }}$} & \multicolumn{2}{|c|}{ 移転再建 } & \multicolumn{2}{|c|}{ 災害危険区域 } & \multirow{2}{*}{ 不明 } \\
\hline & & 再建済み & 未再建 & & 再建済み & 未再建 & 再建済み & 未再建 & \\
\hline 2013.7.28 & 219 & 119 & 30 & 16 & 0 & 30 & 0 & 13 & 11 \\
\hline 2013.11.24 & 218 & 134 & 17 & 16 & 0 & 28 & 0 & 13 & 10 \\
\hline
\end{tabular}

(出典：南蒲生復興部会議資料より筆者作成)

再建を希望していることになる。

この理由としては、「地域やコミュニティへの愛着」「安全面での確認が取れた」といつ た肯定的な意見がある一方で、「資金不足のため」「仕事を続けるため」といつた、何らか の制約を受けて、やむをえず現地再建を選択した世帯も存在する。

時系列を 2012 年まで戻す。このような背景から、復興部では 2012 年 7 月頃から、住宅 再建に加えて、地場産業再生やコミュニティ再生といった復興まちづくりに対する検討が 行われるようになる。その反面で、ワークショップや再建方法別の住民検討会では、住宅 再建の議論が中心となり、復興まちづくりの議論は後置される状況が続いた。結果から述 べれば、復興まちづくりはこの後、2013年初頭までは一連の活動によって得られた住民 意見をもとに、復興部の中心となっている数名が独自に推進したのが実際である。

この後、2013年 3 月に住民による復興計画である「南蒲生復興まちづくり基本計 画」[南蒲生町内会, 2013] が策定され、住民の住宅再建意向もほぼ確定する。加えて、こ の時期には後述する避難道路・避難施設をどのように整備するかという課題が持ち上が り、以降、住民の意識が急速に復興まちづくりへと向かっていく事になる。

\subsection{2 若手の離脱}

このように、地区の復興を担う組織として活動を行う復興部だが、復興部員が 60 代以 上の世帯主を中心としていることが、徐々に組織内部の不満を高める要因ともなってい た。前述の通り、復興部は活動への自由な参加を認めており、活動を開始した時期には 20 代〜 50 代という地区の若手層も参加していた。

しかし、実際の議論では若手側にほとんど発言権が与えられず、これを不服として参加 
を中止する若手住民も存在した。また、自身の財産をいかに保全するかという点を重視 し、復興部内での議論や行政機関との交渉を中心とする復興部員と、長期的なまちづくり に向けて具体的な活動を始めることを重視する若手層という意識差もあり、若手層は復興 部に不満を感じる状況にあった。

このような状況に変化が生まれたのは、2012 年 8 月のことである。復興部への参加を継 続していた若手層の 3 名が、復興部とは別の若手組織を立ち上げ、復興まちづくりについ て実践的な取り組みを行うことを決定した。3 名は、全員が地区の名望家一族の出身であ り、1 名は震災以降に地区の活動に参加し始めたが、残る 2 名は以前より地区の若手リー ダーとして活動を行っていたため、地区に広く地縁を保有しており、その地縁関係によっ て参加者を募り、9月から「えんの会」という名称で活動を開始した。

えんの会は、継続的な参加者 10 名によって構成され、地区の伝統である居久根を含む 緑と地域コミュニティの再生を目標とした。活動は月 1 回の定例会と、休日を利用しての 清掃・緑化活動、まち歩き活動が行われている。活動の理念として自立をうたつており、 創設メンバーが、「外から支援として大きなお金をもらって何かをするというよりは、自 分たちで出来ることからやっていきたい」(Y氏)、「えんの会は、地域の青年団のようにし たい」（N氏）と語るように、復興のための組織というよりは、日常的なコミュニティ組織 が構想されている。

えんの会の特徵としては、復興部との対立を回避したという点がもつとも大きい。えん の会は、住宅再建優先・議論重視の復興部に対抗するために作られた組織であり、そこに は対立関係が予想され得る。

しかし、えんの会は創設メンバーの 3 名が復興部にも在籍し続け、また、えんの会の立 ち上げに向けて、町内会役員や復興部部長との間で組織間の連携が模索されている。復興 部部長が、地区の分断を回避しようとしていたことと同様に、ここでも、若手層の地区の 分断回避への努力が垣間見える。

だが、同会の活動は、復興部との連携を構築する事には成功したものの、居久根再生よ りも災害時の安全確保が優先されるべきという住民意見 ${ }^{7)}$ のなかで、参加者の確保や具体 的な活動の展開が難しい状況が続いた。その後、私有財産である居久根について、まちづ くりという言葉をもって、所有者以外が再生の如何を議論することは正当化されるのかと いう点で、えんの会内部でも活動方針が分かれ、発足から 1 年後に、活動の軸をそれまで の居久根再生から、新たに地区清掃と街路緑化活動へ移すことになる。

とはいえ、このような若手組織が復興部と協調体制を取る形で維持され続けていること は、無意味ではない。現在の南蒲生地区の復興のコンセプトとなっている「新しい田舎」 というフレーズは、居久根再生を巡って行われたえんの会のワークショップの中で生まれ たものである。更に、復興部で議論された課題を持ちかえり、若手としての意見を復興部 へとあげるという経路が用意された事は、地区の復興をはかるうえで重要であろう。この 
意味で、えんの会は復興に向けた地域再編の動きの 1 つであると考えることが出来よう。

\subsection{3 避難施設・避難道路整備}

復興部が直面する課題の最後の 1 つが、避難施設・避難道路整備についての議論であ る。この議論の焦点は、避難タワー、避難道路、県道交差点立体化の整備について、日常 利用上の快適性と災害時の円滑な避難の両者を確保するために、もっとも望ましい施設の 形態と利用方法は何かという点にある。

南蒲生地区では、南北 2 ヶ所での避難タワー建設が計画されており、これについては、 2012 年 12 月に仙台市消防局による避難施設説明会で、計画案が地区側に伝えられた。対 する復興部の方針としては、将来における津波の危険性が避けられない以上、避難施設の 早期建設は望むものの、地区の田園風景の中に、鉄骨造の無骨な建築物が現れることには 賛同できないというものであった。また、避難タワーは日常利用が考慮されていない施設 である為、平時には無用な維持管理費用がかかるという点も問題視された。このような理 由から、復興部は現行計画の変更を求め、住民意見の集約を経て、既存施設の改修や避難 タワーの道の駅化によって、避難施設を日常利用可能な施設とする案を仙台市側に提出し た。

結果としては、住民案は採択されず、現行計画通りに避難タワーを建設し、住民の日常 利用は黙認するという実態利用面での幾分の配慮をしたのみで決着した。地区住民は、こ の結果に全面的な賛同はしておらず、最終的な説明会の場においても、不満の声が聞かれ た。

しかし、住民側でもこの最終案を妥協案として受容し、これ以降、復興部では建設の形 態に関する議論はなされておらず、建設案をもとにした利用面での検討へと議論が移行し ている。

そうした経緯から、2013年11月時点において議論の主軸となっているのは、地区内の 道路拡幅による避難道路整備と、県道塩釜亘理線かさ上げ部分の交差点立体化である。こ のうち避難道路整備については、仙台市の復興計画において既に内陸部への主要な避難道 路の拡幅が決定しており、復興部では拡幅計画の更なる拡充を要望している。対して、交 差点立体化については現行計画で円滑な避難は可能とする仙台市と、円滑な避難は困難で あるとする復興部の間で合意がみられていない。現在も、復興部により交差点立体化を求 める申し入れは続けられているが、復興部部長からは、計画変更は恐らく難しく、現行計 画のまま、平面交差点設置となるであろうという旨が伝えられている。

このような動きを経て、復興部では今後の展開として、津波浸水高の標識設置など、防 災意識を高める啓発活動を行うと共に、避難タワーの建設を待って、避難施設・避難道路 完成後を想定した避難訓練の実施を計画している。

以上のように、復興部は避難施設・避難道路の整備について、 2012 年 12 月に仙台市側 
から計画案を提示されて以降、住民意見をとりまとめ、その実現を要請する活動を続けて きたものの、住民意見のほとんどが、仙台市の計画には採択されないという結果となつた。

しかし、これに対して復興部は強硬な反対運動を展開するという反応は見せず、計画案 に妥協し、実態利用の中で住民意見をどのように実現するかという方向での活動が行われ ている。このような妥協が成立した背景は、現地の観察調査の限りでは、これ以上の計画 変更を求めても実現は不可能であり、むしろ、反対によつて避難施設整備が遅延すること は、地区住民の安全な生活を確保する上で問題がある、という判断があつたとみることが できる。

\section{4. 宮城野区新浜地区}

\section{1 新浜地区の概況と新浜復興の会}

述べてきたような南蒲生地区の取り組みに対して、復興に向けた住民組織が立ち上がり ながらも、調整に困難を抱えているのが新浜地区である。新浜町内会を範囲とする新浜地 区は、南蒲生地区の南側に隣接した農村集落であり、災害危険区域の縮小を経て地区内の 一部が居住可能となつた点など、南蒲生地区とほぼ同様の状況にあるが、被害程度は新浜 地区がやや大きい。地区は約 140 世帯からなり、南蒲生地区の半数程度である。

復興のための住民組織としては、2012 年 2 月に「新浜復興の会 (以下 : 復興の会)」を組 織している。復興の会は、町内会役員および地区内にある19のコミュニティ組織の代表 者から構成され、うち 10 名によって会を中心的に運営する世話人会が組織されている。 南蒲生復興部とは異なり、組織を構成する町内会役員や組織の代表者らは、震災以前から 変わっておらず、地区における住民自治の体制は震災以前と同様のまま維持されている。

活動としては、地区住民の住宅再建意向の取りまとめと、助成制度拡充などの仙台市へ の申し入れ、そして新浜地区のまちづくりの3点が主な内容である。このうち、まちづく りが課題として大きく取り上げられるようになるのは、2013年以降の事であり、2012年 の段階では住宅再建意向と仙台市への申し入れ事項の取りまとめが、会の中心的課題で あつた。

現在は、住民の住宅再建方針もまとまったことから、町内会の下部組織として「新浜町 内会復興部委員会」へと再編されており、復興に向けたまちづくりや防災対策を中心的課 題としている。防災対策では、南蒲生地区と同じく避難夕ワー建設と避難道路整備につい て、仙台市との交渉が行われている。交渉の結果も、仙台市の提示した計画案に沿つた避 難タワー建設と避難道路というものであり、組織課題やその結果という面から見て、復興 の会は南蒲生復興部と近似していると考えることが出来よう。

活動の手法としても、世話人会を中心にワークショップやまち歩きなどが行われてい る。ただし、南蒲生地区とは異なり、一般住民へ活動の経過や結果を説明する住民説明会 
については重視されていない。説明会は、仙台市への要望書に対する回答が来た際など、 大きな変化が起きた場合に随時開催するものとしており、定期的な開催はされていない。

\section{2 復興過程における調整の困難}

新浜地区における調整が困難となつた要因は、2011年10月に仙台市より発表された災 害危険区域指定への対応にさかのぼる事が出来る。この際、新浜町内会は、仙台市に対す る災害危険区域指定の再検討を求める申し入れを、町内会臨時総会で決議し、実施した。 この臨時総会は、震災後の混乱の中で町内会の全世帯に承認が得られたわけではなく、早 急に申し入れを行わなければ、災害危険区域指定の解除が困難になるという切迫感に包ま れた中で、緊急的な措置として、連絡がつき参加可能な世帯のみで決議されたものであつ た。この後、仙台市によつて災害危険区域指定の縮小が行われた際には、新浜地区につい ても一部の現地再建が可能となつた。

しかし、新浜地区の場合、臨時総会に参加しなかつた住民には、災害危険区域の範囲内 で実施される防災集団移転事業に参加し、低費用での内陸部移転を希望していた住民が約 40 世帯存在していた。彼ら移転再建派のうち、災害危険区域の縮小によって、防災集団 移転事業に参加できなくなった住民（以下：区域外移転派）は、全住民の合意を取らずに 決議を強行した町内会に対して強く抗議を行つた。一方、町内会長であるS氏も、新浜地 区の復興は現地再建を基本にするという姿勢を打ち出したことから、現地再建派と区域外 移転派は地区内において対立することとなる。この 2 派の対立は、住みなれた地区への継 続居住を望む高齢層と、家族の安全確保のために内陸移転を求める若手層という形で、世 代的な対立でもあり、2012 年から 2013 年初めの段階では、世帯内での意見対立によって 親子間の会話が断絶した世帯も見られた事が、聞き取り調査より明らかになっている。

とはいえ、世話人の代表をする $\mathrm{E} 氏$ 何もしなかったから危険区域になったと言え ば、現地再建の人に今度は (不満を) 言われたろう」と述べており、当時の状況として、 全住民が納得する方法をとることは難しかつたことも一面の事実ではあろう。

地区の復興を担う復興の会は、世話人の選出や組織の活動方針について、現地再建派と 移転再建派の両派双方の尊重を重視し、一方の派閥を支持するという動きは行われなかつ た。しかし、世話人会における移転再建派とは、災害危険区域内で集団移転事業の対象と なる移転再建派住民を指し、区域外移転派は、町内会への不満から復興の会とは別に独自 の活動を実施する形となった。

$\mathrm{E}$ 氏は組織設立以来のこの状況を憂い、復興の会でも彼らの移転再建に対して行政支援 を求めるなど、対立の解消を模索していたが、区域外移転派の活動に同席し、意見を聞き

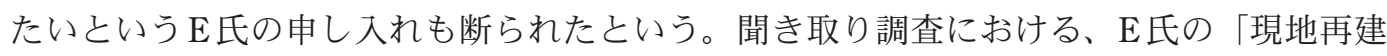
をする人たちには (町内会に) 拒否反応をもっている人もいる」という発言は、このよう な住民の対立を物語るものである。現在においても両組織は、個別に議論をする状況が継 
続しており、地区住民が派閥を問わずに 1 つの場に集つて全体での議論を行うことは、い まもって困難な状況という。

新浜地区の復興過程をまとめれば、新浜地区は南蒲生地区と同様に「I：住宅再建の取 りまとめ」「II : 若手の離脱」「III : 避難施設・避難道路整備」という 3 つの課題に直面し たが、「II : 若手の離脱」が災害危険区域再指定の時期という早期に発生した。そして、 復興の会は、この際に起こった復興の会の基盤である町内会と、地区の若手層である区域 外移転派との間の対立を、現在に至るまで解決しきれていない。そのため、復興の会は調 整型組織としての性格を持って組織されながら、地区の若手層を復興への動きに取り込む ことが出来ず、地区全体の意見集約に困難を抱えていると考えられる。

\section{5. 考察}

\section{1 南蒲生復興部の評価}

南蒲生地区と新浜地区の事例を比較してみた時、両地区は既存の地域住民組織の体制を 利用した復興を担う組織の立ち上げと、組織が取り組んだ課題についてはほぼ同様であり ながら、住民による復興に向けた取り組みの状況には大きな差異が発生したといえる。こ れを、本稿の関心である復興を担う住民組織による調整という点からみたとき、両地区の もっとも大きな相違点は、組織自体が住民による支持を得られていたか否か、という点に 集約される。そして、この支持の有無を規定したものは、「多様な意見の受容」「一般住民 の参加経路の確保」「一般住民の参加機会の確保」の 3 点にあると考えられる。

復興部の活動は、既存の町内会体制再編の一部として組織され、地域内に対立構造を作 り出すことは阻止する、という活動方針に沿い、3 期に整理される復興過程において、 $\lceil\mathrm{I}$ ：住宅再建の取りまとめ」「II：若手の離脱」に対しては、住民意見の対立を調整する 形で活動し、「III：避難施設・避難道路整備」については、継続的な申し入れという穏健 的な形で、地区住民と仙台市との調整を図ってきた。

この取り組みのなかで、復興部は常に、「相手の意見を否定せずに平等な立場で受け止 めてほしい」(H氏) という理念を提示し続け、また、組織自身が復興を主導するわけでは なく、住民意見を集約・調整して計画化し、その計画が住民の意思に沿っているかを確認 し、住民の確認を受けた計画を実現化していくという過程を繰り返し続けた事が、活動の 特徵といえる。

この事実は極めて当たり前のようではあるが、刻々と変動する復興過程の中で、次々と 発生する葛藤と対立に対し、住民組織が調整を行い続け、地区住民もそれを支持するとい うことには多大な労力を必要とする。まして、復興部の場合には、仙台市との交渉で住民 意見の反映に失敗し続けているのが実態であり、地区住民がこの結果に不満を持ち、復興 部を支持しないということも十分に起こり得る。その意味で、今日まで地区の分断を防 
ぎ、住民から地区の復興を担う組織として扱われていることの意義は大きい。その要因と して、多様な意見の受容、一般住民の参加経路と参加機会の確保という活動方針に対する 住民の支持があり、住民は、復興部の失敗に対して、地区全体の代弁者として活動した結 果の失敗であるならば、それは 1 つの結果として受忍し、善後策を検討すべきであるとい う判断に至つたと考えることができる。

\section{2 新浜復興の会の評価}

対して、新浜地区の場合、既存の町内会体制を変更せずに復興の会を組織した際に、町 内会長と若手を中心にした区域外移転派の対立が、復興の会と区域外移転派の対立へとす り替わつた。この過程で、復興の会は区域外移転派住民を軽視しており、多様な意見の受 容を行っていないと理解されたと考えられる。

また、復興の会の特徵として、一般住民の参加経路と参加機会の確保に対する視点が弱 い事があげられる。復興の会は、組織構造のみを見れば既存の地域住民組織による連絡協 議会であり、住民を広く参加させ議論する構造ではない。さらに、その組織の内部に世話 人会という執行部が編成され、方針や計画の策定といつた組織の中核的な活動への一般住 民の参加経路は、十分に用意されているとは言い難い。

一般住民の参加機会についても、一般住民への説明会は重視されておらず、説明会開催 の必要があるか否かは復興の会によって決定される。このことは、現地再建派や移転再建 派にとつては、復興の会による地区の復興の主導とも考えられようが、区域外移転派の支 持を向上させるものとはならなかった。

つまり、復興の会は、既存の地域自治の体制をそのまま復興に適用し、現地再建派と移 転再建派の復興を主導したものの、区域外移転派には自派の軽視と捉えられ、地区住民全 体の支持を受けた調整型組織とはなりきれなかつたといえよう。

\section{3 結語}

これまでみてきたように、本稿では、地区住民による災害復興の取り組みにおいて、地 方都市である島原市の事例から指摘された「調整型組織」[横田, 1995：52］による調整、 すなわち意見集約と行政協調型の交渉が住民による復興に有効である事を、大都市である 仙台市郊外の 2 地区を比較することにより示した。

その中で、本稿による新たな知見として強調すべき事は、次の通りである。調整型組織 は意見集約と行政協調型の交渉という活動方針をもつて設立されるが、この方針が有効に 機能するためには、調整型組織による多様な意見の受容、一般住民の参加経路と参加機会 の確保によって、住民の支持を維持する事が必要になるという点である。このことは復興 を進める際の課題となる、「地域住民組織（まちづくり協議会など）の決定権の不安定性 や、既存のく地域住民を代表表出するためのしくみ>のゆらぎ」[浦野, 1999：101-102］ 
を、既存の体制を基盤としながらも、復興に向けて地区の代表を改めて表出し、安定化さ せた決定権を住民で共有するという社会過程であったとみることができる。その意味で、 新浜地区における調整型組織の困難は、組織設立そのものが誤っていた訳ではなかったと いえよう。

南蒲生地区と新浜地区の活動が、異なる結果となった最大の要因は、この安定化させた 決定権を住民で共有するという社会過程の失敗であった。新浜地区に限らず、被災後の混 乱により住民の招集や議論が困難な一方、可能な限り速やかに、行政機関に対して住民意 見を提出しなければならないという状況は、災害時には、往々にして起こり得ることであ る。時間的制約の中で、初動における意見集約がいささか強引となることは、現実的にや むを得ない所もある。しかし、その後、状況がある程度の落ち着きをみせた段階では、地 区全体として復興をどのように進めれば良いかを、慎重に議論していかなければならな い。

本稿の知見からは、この時、組織のリーダーが住民からの多様な意見を集める体制を構 築できるかどうか、災害以前に培ってきた地区の社会関係を維持し、活用できるかどうか が、復興に向けた長期的な活動の基盤を作るうえで、重要であるといえよう。

とはいえ、調整型組織があらゆる問題に対応できるわけではない。両地区における「避 難施設・避難道路」の問題のように、複数地域にまたがる広域的な課題に対して、単位町 内会規模の活動では限界がある。地域コミュニティレベルでは十分な対応が行えない課題 に対して、調整型組織がどのような対策を取りうるかという点は、今後の検討課題とした い。

\section{付記}

本稿は平成 25 年度笹川科学研究助成「災害復興過程におけるアドホック組織の有効性につい ての研究〜東日本大震災における仙台市南蒲生の復興過程を事例として〜」の成果の一部であ る。最後に、調査にご協力頂いた被災住民ならびに支援団体・仙台市役所の皆様に感謝の意を表 すると共に、1日も早い復興を祈念させて頂きます。

注

1）阪神淡路大震災は都市部の災害であったが、被害が甚大であった長田区などでは、当時でも コミュニティが維持されており、住民による復興への取り組みが注目された。

2） 2013 年度の災害復興学会では「復興を巡る葛藤と対立」をテーマにシンポジウムが開催さ れた。また、地域社会学会の研究例会も、テーマの 1 つを復興における調整としている。

3）地域コミュニティ論では一般に、コミュニティの範囲を「地域」と称するが、仙台市の文書 ではこの範囲を「地区」という表現で記述しており、本稿ではこれに則り南蒲生に関する記述 については、「地区」という表現を用いる。

4）内訳は南蒲生復興部 14 回、えんの会 13 回である。両組織の詳細は後述する。

5）町内会加入世帯数は震災後の転居などで減少しており、2012 年 11 月時点で 235 世帯、2013 
年 11 月時点で 218 世帯となつている。

6）第2線堤とは、主堤の後背に建設される予備的な堤防である。仙台市においては海岸近くを 通る県道塩釜亘理線をかさ上げし、第 2 線堤とすることが計画されている。なお、正確には計 画の対象は県道塩釜亘理線及び市道岡田 107 号線であるが、仙台市はこれを県道塩釜亘理線と 表記しており、本稿ではこれに則り県道塩釜亘理線という表現を用いる。

7） 2012 年 11 月に町内会が実施したアンケート調査において、復興まちづくりの課題について 質問がなされたが、回答した 90 世帯のうち、回答数上位となつた避難施設整備 76 世帯 (84.4\%)、排水機能の復旧 45 世帯 $(50.0 \%)$ 、旧街道の整備・拡幅 26 世帯 $(28.9 \%)$ に対して、 居久根再生を重視したのは 3 世帯 $(3.3 \%)$ であった。

\section{文献リスト}

星山幸男, 2012，「震災から6ヶ月たつてみえてきたもの一一南三陸町と仙台市の今をふまえて」

『日本社会教育学会紀要』 $48: 106-108$.

飯塚智規，2013，『震災復興における被災地のガバナンス——被災自治体の復興課題と取り組み』 芦書房.

石川幹子，2011，「岩沼市（仙台平野南部）の復興計画策定の実態報告——愛と希望の復興」『都 市計画』60(3) : 36-38.

今野裕昭, 1999,「震災対応とコミュニティの変容——神戸市真野地区」岩崎信彦・鵜飼孝造・ 浦野正樹・辻勝次・似田貝香門・野田隆・山本剛郎編『阪神・淡路大震災の社会学第 1 巻 ——被災と救援の社会学』昭和堂, 204-215.

松井克浩, 2008, 『中越地震の記憶—人の絆と復興への道』高志書院.

南蒲生町内会, 2013, 『南蒲生復興まちづくり基本計画』.

南 真一・野島義照, 1994,「奥尻町災害復興計画案と住民の復興イメージについて」『地域安全 学会論文報告集』 $4: 59-67$.

宮定 章, 2007, 「都市インナーエリアの震災復興——御蔵の事例」浦野正樹・大矢根淳・吉川 忠寬編『復興コミュニティ論入門』弘文堂, 113-118.

室井研二，2011，『都市化と災害—とある集中豪雨災害の社会学的モノグラフ』大学教育出版 会.

大堀 研, 2013,「災害後の計画策定と住民参加とが両立する条件についての考察——岩手県釜 石市の事例」『地域社会学会年報』25：127-142.

仙台市, 2011, 「災害危険区域図（A3版・条例第 2 条第 5 号) 」.

仙台市, 2012, 『震災復興地域かわら版みらいんみやぎの』 11.

塩崎賢明・西川榮一・出口俊一・兵庫県震災復興研究セン夕一編, 2005 , 『大震災 10 年と災害列 島』クリエイツかもがわ.

鈴木 広, 1998, 「問題と方法」鈴木広編『災害都市の研究——島原市と普賢岳』九州大学出版 会, 1-54.

田中重好，2013，「『想定外』の社会学」田中重好・船橋晴俊・正村俊之編著『東日本大震災と社 会学』ミネルヴァ書房, 275-328.

谷 謙二, 2012,「小地域別にみた東日本大震災被災地における死亡者及び死亡率の分析」『埼玉 大学教育学部地理学研究報告』32:1-26.

辻中 豊・ロバート $=$ ベッカネン・山本英弘，2009, 『現代の自治会・町内会一一第 1 回全国調 
査に見る自治力・ネットワーク・ガバナンス』木鐸社.

浦野正樹, 1984, 「地域住民組織と地震防災——地域防災への取り組みの実態と課題をめぐって」

『社会科学討究』29(3)：99-151.

浦野正樹, 1999, 「淡路島における区画整理事業の混迷——北淡町富島の事例」岩崎信彦・鵜飼 孝造・浦野正樹 ·辻勝次 ·似田貝香門 · 野田隆 - 山本剛郎編『阪神・淡路大震災の社会学 第 3 巻——復興・防災まちづくりの社会学』昭和堂, 101-111.

浦野正樹・大矢根淳・吉川忠寛編, 2007, 『復興コミュニティ論入門』弘文堂.

山中茂樹, 2006, 「災害復興基本法への道」『先端社会研究』5:287-324.

山下祐介，2013，「広域システム災害と主体性への問い一一心一周縁関係を踏まえて」『東日本 大震災と社会学』ミネルヴァ書房, 27-46.

横田尚俊, 1995,「災害からの復旧・復興過程と地域社会」『社会分析』23：45-58.

(こばやし ひでゆき／東京大学大学院博士課程) （原稿受付 2013 年 12 月 7 日 掲載決定 2014 年 5 月 5 日） 